\title{
Corneal thickness and daily curve of intraocular pressure in suspected and glaucomatous patients
}

\author{
Espessura corneana ecurva diá ria de pressão intra-ocular em pacientes suspeitose \\ glaucomatosos
}

\author{
SebastiãoCronemberger ${ }^{1}$ \\ Nassim Calixto ${ }^{2}$ \\ Leonardo Torqueti Costa ${ }^{3}$ \\ Fábio Martins Soares ${ }^{4}$
}

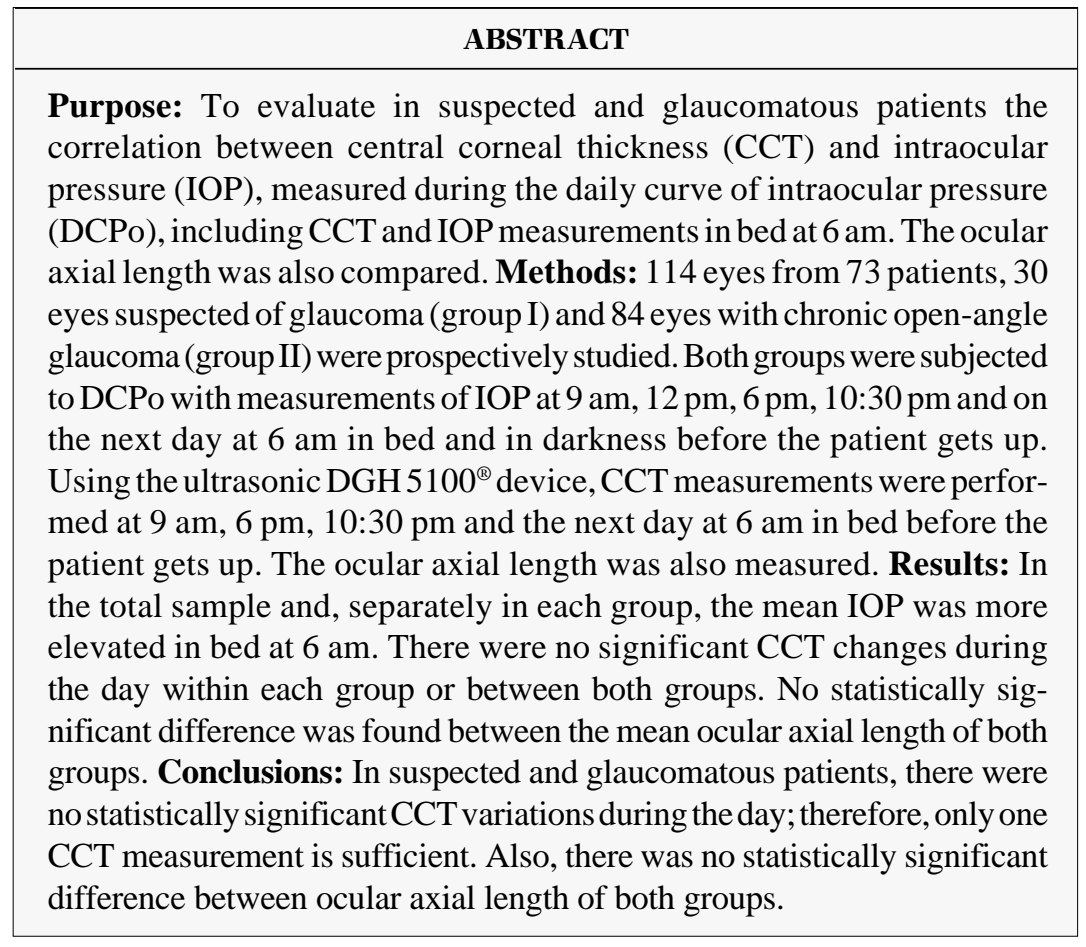

Keywords: Intraocular pressure/physiology; Glaucoma; Cornea/anatomy \& histology; Comparative study; Techniques, measures, measurement equipment
Trabalho realizado no Serviço de Glaucoma do Hospital São Geraldo - MG.

${ }^{1}$ Professor Titular de Oftalmologia da Faculdade de Medicina da Universidade Federal de Minas Gerais - UFMG. Belo Horizonte (MG).

${ }^{2}$ Professor Titular de Oftalmologia da Faculdade de Medicina da UFMG. Belo Horizonte (MG).

${ }^{3}$ Doutorando do Curso de Pós-graduação em Oftalmologia - Faculdade de Medicina da UFMG. Belo Horizonte (MG).

${ }^{4}$ Ex-"Fellow" do Serviço de Glaucoma do Hospital São Geraldo. Belo Horizonte (MG).

Endereço para correspondência: Rua Martim de Carvalho, 410/501 - Belo Horizonte (MG) CEP 30190-090

E-mail: cronem@task.com.br

Recebido para publicação em 30.06.2004

Versão revisada recebida em 22.11.2004

Aprovação em 15.12.2004

Os autores não têm interesse comercial nos produtos e equipamentos utilizados neste estudo.

Nota Editorial: Após concluída a análise do artigo sob sigilo editorial e com a anuência do Dr. Ítalo Mundialino Marcon sobre a divulgação de seu nome como revisor dele, agradecemos sua participação nesse processo.

\section{INTRODUCTION}

In 1957, Goldmann, in a masterly paper about applanation tonometry, stated that the IOP measurement was valid for corneas with a central thickness around $520 \mu \mathrm{m}^{(1)}$. Corneas with a central thickness much different from $520 \mu \mathrm{m}$ present false measurement by tonometry.

IOP measurement may vary according to the central corneal thickness (CCT), that is essentially important in suspected glaucoma, chronic openangle glaucoma and, mainly in patients with normal pressure glaucoma ${ }^{(2-3)}$.

There are many reports showing that corneas with increased central thickness may lead to IOP measurements with falsely high results, whereas corneas with decreased central thickness may lead to IOP measures with falsely decreased values ${ }^{(4)}$.

The applanation tonometer tip applanates a corneal area with a diameter of $3.06 \mathrm{~mm}$, in such a way that the $0.1 \mathrm{~g}$ force applied corresponds to $1 \mathrm{mmHg}$. However, this relation is only true for the corneas with a central thickness around $520 \mu \mathrm{m}^{(5)}$. 
The variations in CCT of normal eyes during the day have also been a subject of reports and controversies ${ }^{(6)}$. Some authors state that there is an increase in corneal thickness during sleep and report a marked range of the corneal thickness during the day ${ }^{(6)}$. Some reports have also shown that antiglaucomatous drugs, such as dorzolamide, do not cause clinically significant changes in corneal thickness ${ }^{(7)}$.

Shah et al. ${ }^{(8)}$, have measured CCT and IOP of 56 eyes from 28 glaucoma suspected patients. Both parameters were measured by the same physician, using an ultrasonic pachymeter and a Goldmann tonometer, respectively, at $8 \mathrm{am}, 12 \mathrm{pm}, 4 \mathrm{pm}$ and $8 \mathrm{pm}$. The authors found no statistically significant correlation between the daily mean variations of IOP and $\mathrm{CCT}^{(8)}$. This was the only paper we found correlating CCT with the IOP measurements at different hours of the day (4 IOP and CCT measurements ${ }^{(8)}$.

We routinely perform the DCPo including IOP measurement in bed at $6 \mathrm{am}$, in order to try to establish the diagnosis in suspected patients or to control the clinical (patients using antiglaucomatous medication) or surgical (patients without antiglaucomatous medication who underwent trabeculectomy for at least six months) treatment efficacy.

In a variable percentage (up to $30 \%$ ) of suspected and glaucomatous patients, the highest IOP value in DCPo occurs in bed at $6 \mathrm{am}^{(9)}$.

Thus, the purpose of this study was to evaluate if there is a correlation, in suspected and glaucomatous patients, between CCT and IOP at different hours of day, including IOP and CCT measurements in bed at $6 \mathrm{am}$. The ocular axial length of both groups was also comparatively evaluated.

\section{METHODS}

One hundred and fourteen eyes from 73 patients, who signed an informed consent term, were prospectively evaluated. We have studied 30 eyes (26.3\%) from 30 suspected glaucoma patients (group I) and 84 eyes (73.7\%) from 43 patients with chronic open-angle glaucoma with typical visual field changes (group II). We have considered suspected glaucoma patients those presenting no visual field loss and IOP values from 19 to $25 \mathrm{mmHg}$ in isolated tonometries and/or increased optic disc excavation (C/D ratio from 0.6 to 0.8 ) and/or asymmetry in optic disc excavation (C/D ratio) greater than 0.2 .

The patients of both groups included in this study had normal corneas on biomicroscopy. Patients with angle-closure or secondary glaucoma were excluded.

Suspected patients were not using any ocular medication. Fifty-one eyes (60.7\%) from group II were under monotherapy or combined topical antiglaucomatous treatment and 33 eyes $(39.3 \%)$ had already under gone trabeculectomy with a minimum follow-up of at least six months and were not using any antiglaucomatous medication.

In the glaucomatous patients, the measurements of the parameters of both eyes were considered, whereas in the suspected patients only one eye was considered, the ones with the highest IOP and/or highest C/D ratio. Both groups were submitted to DCPo with IOP measurements performed with the Goldmann applanation tonometer model R900 connected to a slitlamp at $9 \mathrm{am}, 12 \mathrm{pm}, 6 \mathrm{pm}, 10: 30 \mathrm{pm}$ (patients seated) and the next day at $6 \mathrm{am}$, in bed before the patient gets up, with the Perkins applanation tonometer.

Using the ultrasonic DGH $5100^{\circledR}$ device, first, the ocular axial length measurement was performed, then, the CCT measurements, always with an approximate five-minutes interval between CCT and tonometry at 9 am (after tonometry), $6 \mathrm{pm}$ (before tonometry), 10:30 pm, after tonometry, and the next day, at $6 \mathrm{am}$, in bed, before the patient gets up, after tonometry. Three measurements of CCT and three of the ocular axial length were performed and their means were considered in the study. The measurements of all parameters were performed by two of the authors (SC and NC). We did not perform CCT measurement at $12 \mathrm{pm}$.

The data were tabulated and analyzed by Epi Info 6.04b and Microsoft Excel 2000, using the ANOVA test.

\section{RESULTS}

Fifty-three eyes (46.5\%) were from male and 61 (53.5\%) from female patients. The mean age of the patients was $61.0 \pm$ 15.5 years (group I) and $60.5 \pm 14.4$ years (group II).

In the total sample and, separately in each group, the mean IOP was more elevated in bed at 6 am, decreasing in the following hours (Table 1). Comparison between the two groups showed a statistically significant lower mean IOP in group I (suspected glaucoma) than in group II (chronic open-angle glaucoma) at all hours of measurements. In the suspected group, in $5(16.7 \%)$ of 30 eyes, the diagnosis of glaucoma was confirmed by the presence of a hypertensive IOP peak in bed at 6 am. In $40(47.6 \%)$ of 84 glaucomatous eyes, DCPo showed that the IOP was not appropriately regulated, and a hypertensive IOP peak was found in bed at $6 \mathrm{am}$.

In group I, the mean value of ocular axial length was 23.07 $\pm 0.95 \mathrm{~mm}$ and in group II it was $23.62 \pm 1.27 \mathrm{~mm}$, with no statistically significant difference between them $(p>0.05)$.

CCT did not change significantly among the different scheduled hours in groups I and II. Also, CCT variation was not comparatively evident between the groups (Table 2).

In spite of Pearson's correlation coefficient between CCT and IOP at different hours being positive and statistically significant, the values of this correlation were low, a little higher at 6 am in group I than at other hours, but of doubtful clinical significance in both groups (Table 3).

\section{DISCUSSION}

CCT may change with some factors, such as gender, race, age and time of the day. It has been noted that night edema reabsorption rate per hour is significantly higher in young adults than in the elderly ${ }^{(10)}$. A smaller corneal thickness was found in male subjects ${ }^{(11)}$. 


\begin{tabular}{|c|c|c|c|c|}
\hline $\begin{array}{l}\text { Intraocular pressure } \\
(\mathrm{mmHg})\end{array}$ & $\underset{n=30}{\text { Group I }}$ & $\underset{n=84}{\text { Group II }}$ & $\begin{array}{c}\text { General } \\
n=114\end{array}$ & $\begin{array}{c}p \text { value } \\
\text { (intergroups) }\end{array}$ \\
\hline $6 \mathrm{am}$ & $17.2 \pm 3.7$ & $20.4 \pm 5.5$ & $19.6 \pm 5.2$ & 0.015 \\
\hline $9 \mathrm{am}$ & $15.0 \pm 3.3$ & $17.0 \pm 3.9$ & $16.5 \pm 3.8$ & 0.043 \\
\hline $6 \mathrm{pm}$ & $13.3 \pm 2.9$ & $15.2 \pm 3.5$ & $14.7 \pm 3.5$ & 0.030 \\
\hline $10: 30 \mathrm{pm}$ & $12.6 \pm 3.0$ & $15.0 \pm 3.4$ & $14.4 \pm 3.4$ & 0.004 \\
\hline$p$ value (intragroup) & 0.000 & 0.000 & 0.000 & - \\
\hline \multicolumn{5}{|l|}{$n$ : number of eyes } \\
\hline
\end{tabular}

\begin{tabular}{|c|c|c|c|c|}
\hline $\begin{array}{l}\text { Central Corneal Thickness } \\
(\mathrm{mm})\end{array}$ & $\underset{n=30}{\operatorname{Group} I}$ & $\underset{n=84}{\text { Group II }}$ & $\begin{array}{c}\text { General } \\
n=114\end{array}$ & $\begin{array}{c}p \text { value } \\
\text { (intergroups) }\end{array}$ \\
\hline $6 \mathrm{am}$ & $538.2 \pm 38.7$ & $535.2 \pm 35.5$ & $536.0 \pm 36.2$ & 0.926 \\
\hline $9 \mathrm{am}$ & $529.0 \pm 33.7$ & $528.8 \pm 35.3$ & $528.6 \pm 34.7$ & 0.997 \\
\hline $6 \mathrm{pm}$ & $530.3 \pm 32.6$ & $527.7 \pm 34.8$ & $528.4 \pm 34.1$ & 0.939 \\
\hline $10: 30 \mathrm{pm}$ & $534.3 \pm 36.0$ & $530.1 \pm 36.8$ & $531.2 \pm 36.5$ & 0.869 \\
\hline$p$ value (intragroup) & 0.741 & 0.521 & 0.334 & - \\
\hline $\mathrm{n}$ : number of eyes & & & & \\
\hline
\end{tabular}

\begin{tabular}{|lccc|}
\hline \multicolumn{2}{|c|}{ Table 3. Pearson's correlation index: central corneal thickness $\mathbf{x}$ intraocular pressure } \\
CCT $(\mu \mathrm{m})$ X IOP $(\mathbf{m m H g})$ & $\begin{array}{c}\text { Group II } \\
\mathbf{n}=\mathbf{8 4}\end{array}$ & $\begin{array}{c}\text { General } \\
\mathbf{n}=\mathbf{1 1 4}\end{array}$ \\
& $\mathbf{n}=\mathbf{3 0}$ & 0.415 & 0.423 \\
$6 \mathrm{am}$ & 0.631 & 0.304 & 0.319 \\
$9 \mathrm{am}$ & 0.421 & 0.000 & 0.009 \\
$6 \mathrm{pm}$ & 0.510 & 0.391 & 0.394 \\
$10: 30 \mathrm{pm}$ & 0.516 & 0.448 & 0.425 \\
CCT: central corneal thickness; IOP: intraocular pressure; $\mathrm{n}$ : number of eyes & & 0.001 \\
\hline
\end{tabular}

The daily range of CCT is still controversial. For some authors, it represents a mean of $0.006 \mathrm{~mm}$ variation. During the night, the corneal edema is of about $4.5 \%$ (or $0.026 \mathrm{~mm}$ ) of the day mean thickness ${ }^{(10)}$. Another paper showed a larger daily variation of CCT, ranging from 2.1 to $14.3 \%{ }^{(12)}$.

In this paper, it was seen that in suspected and glaucomatous patients, although the mean CCT in both groups has been a little higher in bed at 6 a.m. than at other hours, there was no statistically different variation among the different scheduled hours in which CCT was measured. It was also noticed that there is a mild tendency to decrease in the mean CCT of both groups in the morning period and to slight increase until the end of night (measurements at 10:30 pm) (Table 2).

Also for IOP, the mean values decreased in the morning period with mean higher values in bed at 6 am than at other hours in both groups (Table 1).

It was also found that there was a moderate, positive correlation between the mean IOP and CCT values in bed at $6 \mathrm{am}$, with no elements to explain this finding.

Although the authors of one paper ${ }^{(9)}$ did not perform IOP and CCT measurements in bed at $6 \mathrm{am}$, as it was done in this paper, they also found in glaucoma suspected patients no statistically significant correlation between the measurements of both parameters at $8 \mathrm{am}, 12 \mathrm{pm}, 4 \mathrm{pm}$ and $8 \mathrm{pm}$.

The results of this paper could not be compared with those reported in the national literature ${ }^{(13-14)}$ due to a great difference in methodology. However, in one of these papers ${ }^{(13)}$, the mean CCT values in glaucomatous patients were very close to those we have found.

Due to the CCT and IOP correlation, some authors indicate ultrasonic pachymetry as the indispensable ancillary examination for ocular hypertension evaluation ${ }^{(2)}$. The same is also valid for patients with normal pressure glaucoma, in order to avoid a "subtreatment" ${ }^{4,15)}$.

With the findings of this paper it is possible to affirm that only one CCT measurement must be performed in case of doubt related to diagnosis, that means, in patients in whom CCT may have influenced the management. However, the measurement that was obtained must be correlated to the IOP value found at the same time.

In concordance with the diurnal variation of intraocular pressure in healthy, suspected, and glaucomatous eyes ${ }^{(9)}$, the present study has shown that in suspected patients, IOP measurements in bed at 6 am was very important for the esta- 
blishment of the diagnosis of glaucoma in $16.7 \%$ of the eyes. Also, almost half of the glaucomatous eyes (47.6\%) did not present the appropriately regulated IOP in DCPo, presenting a hypertensive IOP peak in bed at $6 \mathrm{am}$.

\section{CONCLUSIONS}

In suspected and glaucomatous patients, there were no statistically significant CCT variations during the day; therefore, only one CCT measurement is sufficient. Also, there was no statistically significant difference in ocular axial length between both groups.

For the early diagnosis of suspected patients and the appropriate follow-up of glaucomatous patients under the clinical treatment or after surgical treatment, the investigation of IOP through DCPo including IOP measurement in bed at 6 am seems to be of utmost importance, keeping the CCT measurements as an ancillary method in cases of doubt related to the diagnosis.

\section{RESUMO}

Objetivo: Verificar em pacientes suspeitos de glaucoma e glaucomatosos se existe correlação entre a espessura corneana central (ECC) e a pressão intra-ocular (Po), medidos durante a curva diária de pressão intra-ocular (CDPo), incluindo-se as medidas da ECC e da Po às 6:00 horas da manhã no leito. Avaliar também comparativamente o diâmetro axial ânteroposterior (Diâm. axial) em ambos os grupos. Métodos: 114 olhos de 73 pacientes selecionados no Serviço de Glaucoma do Hospital São Geraldo, foram divididos em dois grupos: grupo I - pacientes suspeitos de glaucoma e grupo II - pacientes glaucomatosos. Ambos os grupos foram submetidos à CDPo com medidas da Po nos horários de 9h00, 12h00, 18h00, $22 \mathrm{~h} 30$ (paciente sentado) e no dia seguinte às $6 \mathrm{~h} 00$ no leito e no escuro antes de o paciente levantar-se. Utilizando-se o paquímetro ultra-sônico DGH $5100^{\circledR}$, realizou-se a medida do Diâm. axial e as medidas da ECC nos horários de 9h00 (após a tonometria), $18 \mathrm{~h} 00$ (antes da tonometria), 22h30 (após a tonometria) e no dia seguinte às 6 h00 no leito antes de o paciente levantar-se (após a tonometria). Resultados: $\mathrm{Na}$ amostra global e, separadamente em cada grupo, a Po média foi mais elevada às $6 \mathrm{~h} 00$, decrescendo nos outros horários da CDPo. Comparando-se os grupos, verificou-se que a Po média foi significativamente menor no grupo I (suspeitos de glaucoma) em todos os horários das medidas. A espessura corneana central não variou significativamente entre os diferentes horários intragrupo. Também não se evidenciou diferença, compa- rativamente, de espessura corneana entre os dois grupos. $\mathrm{O}$ Diâm. axial médio do grupo I foi de 23,07士0,95 mm e o do grupo II, 23,62 $\pm 1,27 \mathrm{~mm}$, não tendo havido diferença estatisticamente significativa entre eles. Conclusões: Em pacientes suspeitos de glaucoma e glaucomatosos, não houve variação significativa da ECC em diferentes horários, o que significa que apenas uma medida da ECC é suficiente. Não se evidenciou diferença estatisticamente significativa na ECC entre pacientes suspeitos de glaucoma e glaucomatosos. Também não houve diferença estatisticamente significativa no Diâm. axial entre os dois grupos.

Descritores: Pressão intra-ocular/fisiologia; Glaucoma; Córnea/ anatomia \& histologia; Estudo comparativo; Técnicas, medidas, equipamentos de medição

\section{REFERENCES}

1. Goldmann H. Applanation tonometry. In: Newell FW, ed. Glaucoma Transactions of the Second Conference. New York: Josiah Macy Jr. Foundation; 1957. p.167-220.

2. Herndon LW, Choudhri SA, Cox T, Damji KF, Shields MB, Allingham RR. Central corneal thickness in normal, glaucomatous, and ocular hypertensive eyes. Arch Ophthamol. 1997;115(9):1137-41.

3. Ehlers N, Hansen FK. Central corneal thickness in low-tension glaucoma. Acta Ophthalmol (Copenh). 1974;52(5):740-6.

4. Bron AM, Creuzot-Garcher C, Goudeau-Boutillon S, d'Athis P. Falsely elevated intraocular pressure due to increased central corneal thickness. Graefes Arch Clin Exp Ophthalmol. 1999;237(3):220-4.

5. Shah S, Chatterjee A, Mathai M, Kelly SP, Kwartz J, Henson D, McLeod D. Relationship between corneal thickness and measured intraocular pressure in a general ophthalmology clinic. Ophthalmology. 1999;106(11):2154-60.

6. Harper CL, Boulton ME, Bennett D, Marcyniuk B, Jarvis-Evans JH, Tullo $\mathrm{AB}$, Ridgway AE. Diurnal variations in human corneal thickness. Br J Ophthalmol. 1996;80(12):1068-72.

7. Wilkerson M, Cyrlin M, Lippa EA, Esposito D, Deasy D, Panebianco D, et al. Four-week safety and efficacy study of dorzolamide, a novel, active topical carbonic anhydrase inhibitor. Arch Ophthalmol. 1993;111(10):1343-50.

8. Shah S, Spedding C, Bhojwani R, Kwartz J, Henson D, McLeod D. Assessment of the diurnal in central corneal thickness and intraocular pressure for patients with suspected glaucoma. Ophthalmology. 2000;107(6):1191-3.

9. Sampaolesi R, Calixto N, De Carvalho CA, Reca R. Diurnal variation of intraocular pressure in healthy, suspected, and glaucomatous eyes. Bibl Ophthalmol. 1968;74:1-23.

10. Hansen FK. A clinical study of the normal human central corneal thickness. Acta Ophthalmol (Copenh). 1971;49(1):82-9.

11. Asbirk PH. Corneal thickness. I. Age variation, sex difference and oculometric correlations. Acta Ophthalmol (Copenh). 1978;56(1):95-104.

12. Edmund C, la Cour M. Some components affecting the precision of corneal thickness measurement performed by optical pachometry. Acta Ophthalmol (Copenh).1986;64(5):499-503.

13. Meirelles SHS, Stohler NSF, Mariano MP, Yamane R, Yamane Y. Espessura corneana no glaucoma de pressão normal. Rev Bras Oftalmol. 2001;60(1):56-64.

14. Sakata K, Selonke I, Schmitt A, Garndinetti A, Sakata V, Guerra DR, Sakata L. Glaucoma de pressão normal e espessura corneana central. Arq Bras Oftalmol. 2002;65(6):619-22.

15. Emara BY, Tingey DP, Probst LE, Motolko MA. Central corneal thickness in low-tension glaucoma. Can J Ophthalmol. 1999;34(6):319-24. 